\title{
Historein
}

Vol 8 (2008)

Performing Emotions: Historical and Anthropological Sites of Affect

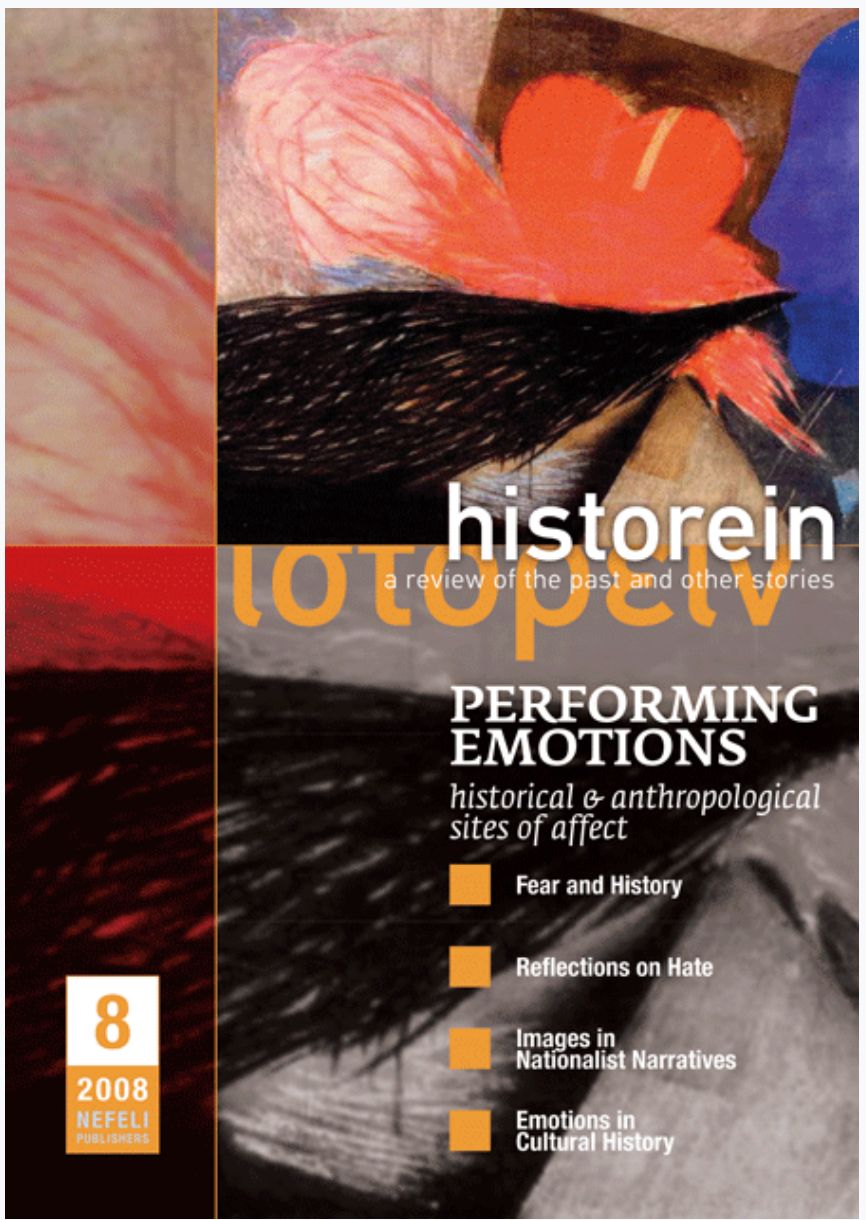

Deep Images in Nineteenth- Century Nationalist Narrative

Alberto Mario Banti

doi: $10.12681 /$ historein.37

Copyright @ 2012, Alberto Mario Banti

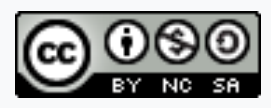

This work is licensed under a Creative Commons Attribution-NonCommercialShareAlike 4.0.

To cite this article:

Banti, A. M. (2009). Deep Images in Nineteenth- Century Nationalist Narrative. Historein, 8, 54-62. https://doi.org/10.12681/historein.37 


\section{Deep Images \\ in Nineteenth- \\ Century Nationalist \\ Narrative}

\section{Alberto Mario Banti}

University of Pisa
1

The analyses carried out by George Mosse have already shown very well the emotional nature of nineteenth-century nationalist discourse in Germany as well as elsewhere in Europe.' Yet, an exploration of the internal texture of nationalist political discourse can help in further clarifying its ways of working, considering that it is because of its internal texture that this discourse displays an enormous emotional power.

Now, I am convinced that the nationalist discourse derives its huge emotional power by a morphology structured around what we might call "deep images". What, in this context, can these images be? They are pictures, allegorical systems, and narrative constellations incorporating a set of specific values that belong to the very core of the nationalist belief.

And why are they "deep" images? They can be described in this way because they have to do with "primal" facts (birth/death, love/ hate, sexuality/reproduction); and also because they are elaborated through materials that come from a pre-existent discursive continuum, in some cases centuries old; the value of these deep images rests precisely in the fact that they are positioned within such a continuum, for this is what makes the images easily recognisable, but at the same time, adaptable within new discursive contexts. ${ }^{2}$

What then are these images? I will concentrate on three of them which - in my opinion - deserve special attention. 
The first is the image of kinship. It is by means of such a straightforward and easily accessible image that one of the basic matrices of national discourse is formed. Imagining the nation as a system of kinship - that is to say, as a network of relationships which extends backwards to preceding generations, acts in the here and now for contemporary members of the community, and projects itself towards the future generations to come - means essentially two things.

Firstly, it implies imagining the nation as a community of descent, endowed with its own historicalness. Secondly, it involves presenting the biological link as a basic fact - hence the recourse, initially naiive (if one can put it that way), to terms such as 'race' or 'blood' to denote the connections that bind individuals to the community. Finally, it follows that an entire linguistic subsystem is bound up with the idea of the nation as a community of kinship: the territory is the "motherland/ fatherland'; the founders of national movements or new nation-states are the 'fathers of the nation'; the national 'community' is a 'brotherhood', and the image of brotherhood/sisterhood becomes an essential way of denoting the type of community that is to be maintained.

The strength of the conception of the nation as a family/parenthood lies in the fact that it reduces the abstraction in the idea of nation, and gives it back a simple and immediate intelligibility. But this operation acquires an even greater strength because this first image is profoundly connected to a second deep image, identifiable with the conceptual constellation of love/honour/virtue.

In nationalist discourse, romantic love is considered as an essential prerequisite for the foundation of steady families. It seems to me that hidden behind this widespread elaboration, there is a kind of biopolitical anxiety: ${ }^{3}$ if what constitutes the essence of a nation is the existence of a consistent genealogical lineage, this lineage has to be reproduced and defended. Reproduction and protection are requirements fulfilled by the values of honour and virtue, whose contents are clearly gender-specific.

In a poem, Matilde (1824), written by Giovanni Berchet, a poet who was very popular in the Italian Risorgimento period, we find a strongly emotional treatment of this crucial theme. ${ }^{4}$ The poem narrates the very brief story of Matilde, a young girl who is sleeping and who has a nightmare; she dreams that her father has decided that she must marry an Austrian soldier. She does not want to at all, because the Austrians are the enemies of Italy; and so she is desperate, absolutely desperate, because this is a destiny that terrifies her, and at a crucial point in the poem she turns to her father and says, "Father you cannot, you must not do anything which will mix the blood of our oppressed people with the blood of the oppressor." Luckily, the nightmare ends. Her father does not want to marry her to an Austrian solider. The order of the reality is restored. Nightmares are nightmares, even though Matilde remains prey to a sense of fear, thinking of the enemy and of the terrible future she would have had marrying one of them. 
In the story of Matilde, the responsibility of guarding the conservation of genealogy and preserving it from 'miscegenation' is attributed to the figure of the father (significantly a figure within the internal circle of the kinship web). In many other cases, this task is committed to other male characters: brothers, sweethearts, husbands. Young as they are, they are the typical combatant heroes. They have to be able to defend the nation by arms, or, in any case, deal with public matters. Most of all, they have to be able to defend the heroines of the nation. Typically, the heroines are described as women who have to take care of the family, and to assist and support the men; furthermore, they must demonstrate a respectable sexual behaviour, characterised by a strict monogamous chastity; in its turn, this is considered as the essential guarantee of a correct development of the genealogical lines, which structure the nation as a kinship community. As a consequence, this conception can explain the frequency with which stories of rape, perpetrated by the enemies or traitors of the heroines of the nation, are included in many nationalist narratives. These stories want to stress that the enemy threat is not only directed at the political autonomy of the nation, but also at its sexual-genealogical integrity: and the real value of the male heroes lies in their capability to guard the chastity and purity of their women. ${ }^{5}$ When it does not happen, the only fate the assaulted women have is death: in the form of suicide in order to preserve their purity, or in the form of a psycho-physical collapse as an extreme form of expiation.

Yet this question of the death of the raped heroine - typical in the nationalist narrative -deserves further comment. Why should an unlucky woman, subjected to sexual aggression by a traitor or enemy, also die, without any other solution? The narrative development has no realism in itself; but it has a functional ratio: the death is not only an expiatory sacrifice, but it is also a kind of reassurance that, if the rapist should have got the woman pregnant, no deviant lineage could spring from it.

\section{4}

The ethical values incorporated in the conceptual network composed by kinship/love/honour/ virtue are completed by a further deep image, the sacrifice, which introduces the themes of suffering, mourning and death. Its enormous importance resides in the fact that it provides the basis for national belonging as a sacred experience. This in turn gives the nation a religious dimension, because it opens up a path - one that is incredibly full of resonance - towards the understanding and ennoblement of death.

In an insightful article on "religion as a cultural system", Clifford Geertz wrote that the purpose of a religious system is to try and provide an order for dealing with experiences and images which seem impossible to interpret using other, non-metaphysical conceptual tools. Yet, this does not mean that religion is an instrument to sweeten the experiences of life. On the contrary, if one considers that two important aspects of life, illness and grief, are at the centre of religious attention in general, then it is also necessary to recognise that the religious means of dealing with these experiences are directed not so much at exorcising as including them in a system rendered full of meaning: "As a religious problem, the problem of suffering is, paradoxically, not how to avoid suffering but how to suffer, how to make of physical pain, personal loss, worldly defeat, or the helpless contemplation of other's agony something bearable, supportable - something, as we say, sufferable."6 


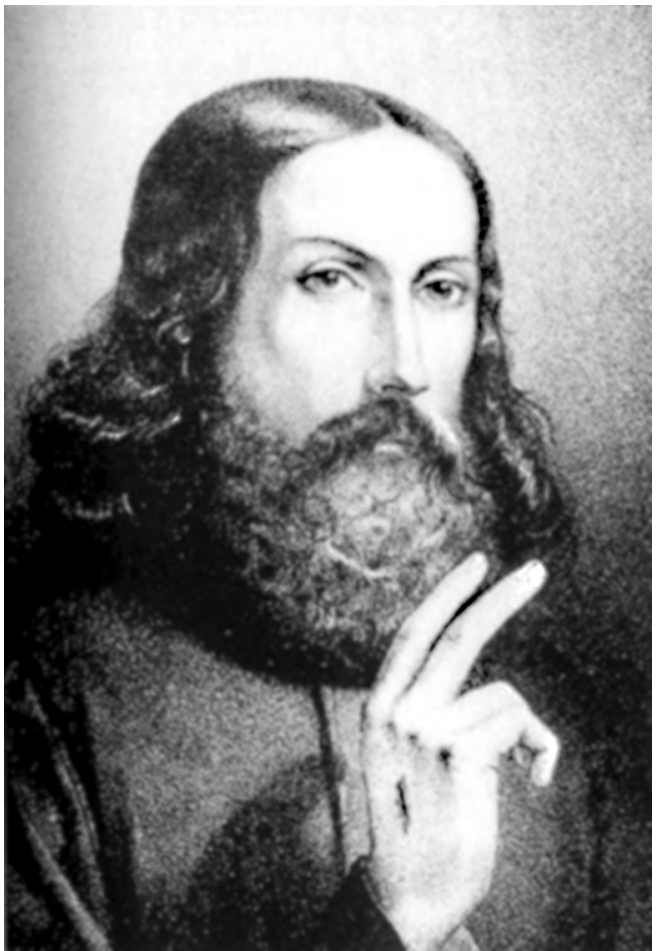

Figure 1: Portrait of Garibaldi, transfigured into the Redeemer in order to avoid censorship, print, 1850, Museo Centrale del Risorgimento, Rome
In the nationalist discourse the essential, sanctifying factor is the image of self-sacrifice or martyrdom, exactly because it explains the experiences of death, and it sorts them into an ethical hierarchy. Extraordinarily important here is the primary nexus established between the patriotic martyrs and the figure of Christ as the original model of martyrdom. From many points of view, the national hero can be considered to be a sort of transposition of the figure of Christ to a different semiotic field; like Jesus Christ, the hero of many nationalist narratives is a witness, because he is destined to die or to suffer. The sacrifice is the proof that a scandal exists; in the case of Christ it is an ethical scandal; in the case of national narratives it is an ethic and political scandal at the same time (the oppression of the nation). As with the death of Jesus Christ, although obviously on a very different level, the death of the hero is also a great sacrificial suffering, but a suffering that can redeem the entire national community; it is a sacrifice which acts as an example and a stimulus towards the liberation of the entire national community. From the many figures that can show the superposition of the hero onto the image of Christ, one is particularly remarkable. It is a print from 1850 that shows Garibaldi represented as the Redeemer. In 1850 Garibaldi was in exile; his traces had disappeared, and some thought that he might even be dead; but aside from that Garibaldi was already a hero in the patriotic imagination who had suffered, both because of the political-military defeat of the Roman Republic in 1849 and because of the death of his wife, Anita, which had occurred while fleeing after the fall of the Republic to conquering French troops. From these considerations derives the representation of the hero as Christ, and particularly a suffering Christ, who has on his hand the mark of the nails, the stigmata.

This way of approaching suffering and death is what transforms the national-patriotic ideals into something sacred, something that has the features of a religious belief. And precisely from this derive the religious resonances found in national discourse, which speaks incessantly of 'martyrdom', 'sacrifice', 'faith', 'missions', 'regeneration', 'resurrection', 'revival', 'holy wars' and 'crusades'.

In addition, this sacral way of understanding the nation offers an explanatory and ennobling framework not just for the death of 'our' martyrs, but also for the death of the 'others' (the 'enemies', the 'foreigners'). These latter deaths are thereby rendered acceptable, given that they too were 'sacrificial' for the good of the community. 
What is more is that, very often, all these deep images are strictly interconnected within the same narratives or iconographical representations of the nation.

Two examples may help to shed light on the working of this discursive system. Between 1844 and 1846, Francesco Hayez, an Italian painter, produced the third version of a painting depicting a famous episode in Risorgimento myth, namely, the Sicilian Vespers, an insurrection that broke out in Palermo, on Easter Monday, 1282 (Figure 2).?

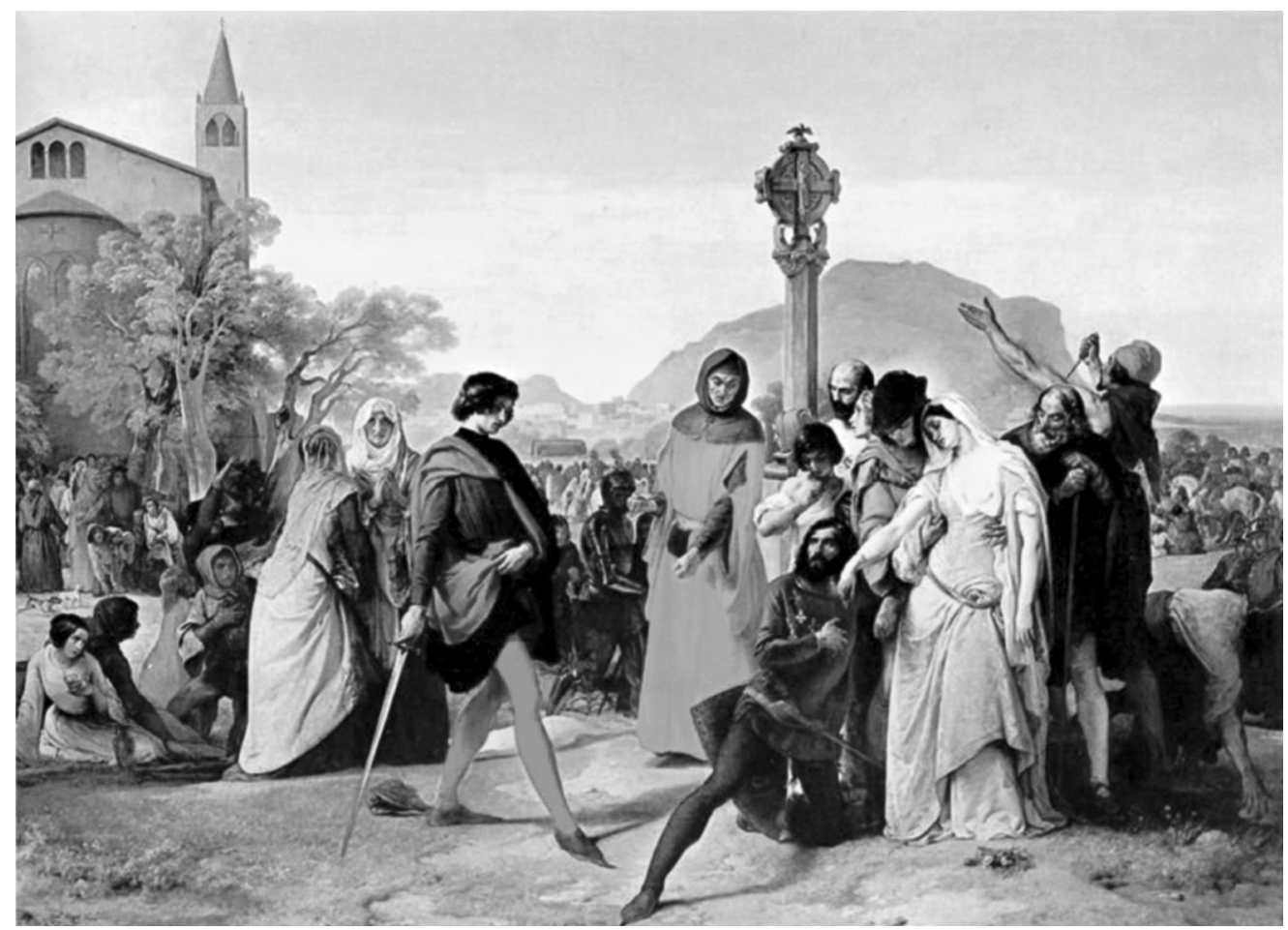

Figure 2. Francesco Hayez, The Sicilian Vespers, oil on canvas, 1844-46,

Galleria Nazionale d'Arte Moderna, Rome

Although this thirteenth-century episode had little in common with the political experience of early nineteenth-century Italy, it acquired an intense symbolic value in Italian Risorgimento political writing, once the Sicilian rebellion against Angevin oppression came to be inserted into the long sequence of rebellions launched to free Italy from foreign oppressors.

The particular episode depicted by Hayez unfolded as follows: Sicily is under the French yoke, and the French soldiers and nobles, not content with having robbed the Sicilians of their liberty, could not resist humiliating them too, insulting their women and sometimes even subject- 
ing them to sexual assault. One day, Easter Monday, as many Sicilian families are setting out to Mass, a French soldier chances to stop one of these families and says that the young wife, who is making her way to church with her relations, is in fact concealing a knife beneath her dress. There is no truth in the claim, as he knows full well; it is just an excuse to lay hands on her, and to uncover a breast; it is just one more way of insulting the Italians, by showing that they are not able to protect their women. On this occasion, however, the Frenchman miscalculates, for the Italians' response is immediate and, as the husband supports the young woman, who faints on account of the insult she has suffered, one of his brothers draws his sword and mortally wounds the Frenchman, who, significantly enough, falls on his knees before the woman. In the meantime, a man of the people draws the attention of one and all to what has just occurred: this is the last straw, the outrage that is about to precipitate the revolt of the Sicilians/Italians, and that will lead to the expulsion of the French from Sicily.

Five aspects of the picture deserve further comment: Firstly, Hayez shows very clearly that the spark precipitating the revolt against the foreign oppressor ignites deep within the national kinship structure, or the family, and then spreads in concentric circles to the rest of the community; secondly, the nationalist rhetoric animating the narrative emphasises the twofold nature of the oppression, which is directed against liberty and, at the same time, against the nation's honour; and it is worth pointing out that in this case - as with nationalist discourse in general - to speak of honour is to speak of a system of values with an unequivocal sexual and gender content; thirdly, in this latter respect, then, the picture complies with a characteristic gender asymmetry, in that the men act while the women display all their precious fragility; fourthly, at the same time, the outraged woman calls to mind a common form of national allegory, whereby a young woman with a bared breast symbolises the capacity of the mother-fatherland to feed its sons the values of liberty; in this case, the intertextual system imagined by Hayez suggests that the woman in the painting is not only that particular Sicilian but is also, at one and the same time, an allegory of the nation, and so are all Italian women; since that is how things stand, the outrage suffered by the woman is not just an attack on that specific person and on the members of her family, but is also an attack on the whole Italian nation; finally, the religious context, with the cross looming over the scene and the church in the background, recalls the close link between national and Christian discourse.

Many other paintings by Hayez feature patriotic subjects, invariably handled with originality and bravura, but one in particular merits further scrutiny, precisely because the theme of national allegory, merely touched upon in the Vespers, is tackled with great aesthetic and communicative boldness. I refer here to Meditation, a picture from 1851, better known as Italy after 1848 (Figure 3). ${ }^{8}$

It is an allegory that draws directly upon the iconographic tradition described above: a young, sad and very alluring woman, wearing a light smock that leaves a breast bare, holds a book on the spine of which History of Italy is written, and a crucifix, on which the dates of Milan's rebellion against the Austrians ("18.19.20.21.22 March 1848") are painted.

The picture unites, in one and the same context, the various elements of the national discourse considered above, in a combination which from an iconographic point of view is highly original. Indeed, one may discern allusions to the nation (the allegory), to history and to the past (the 


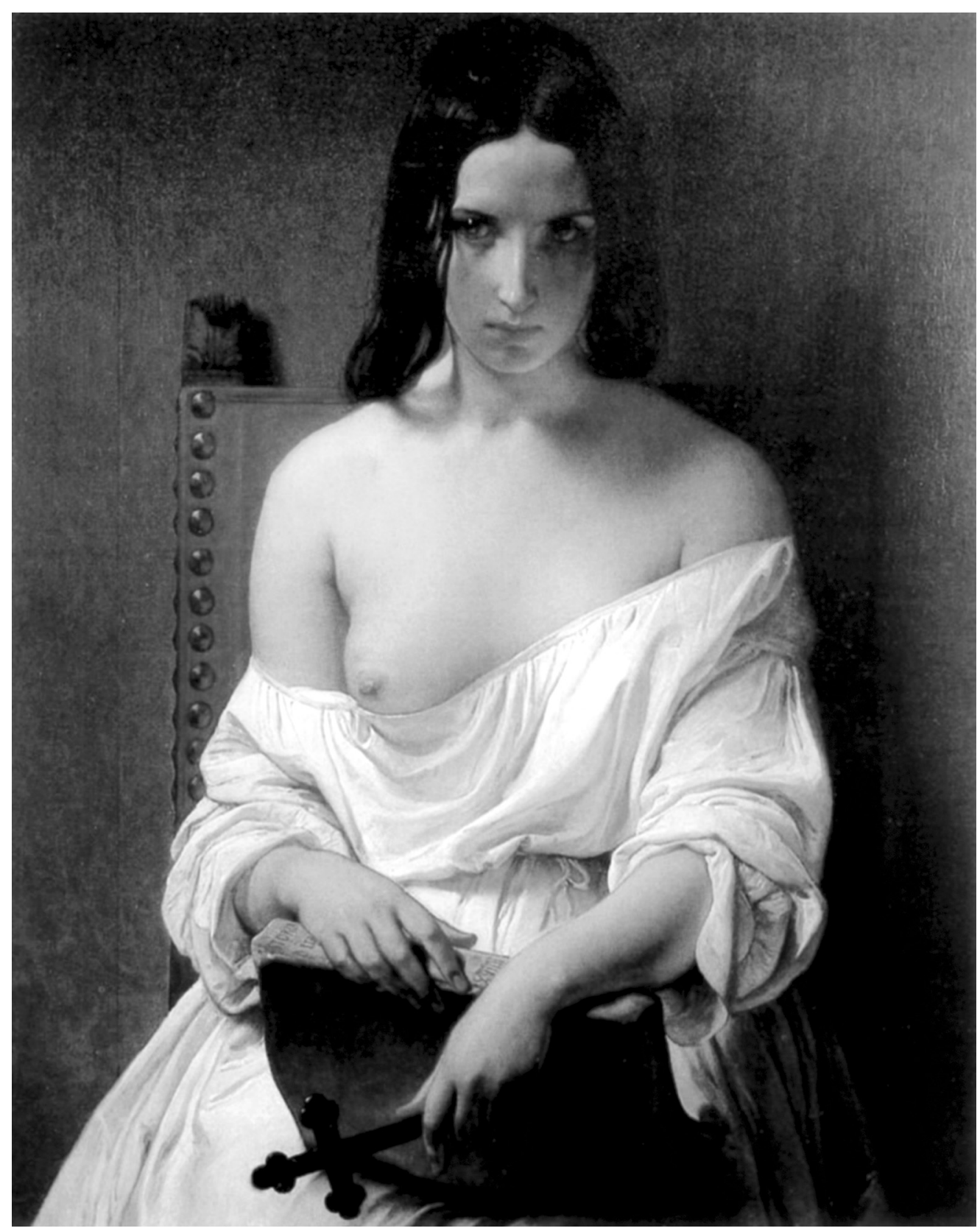

Figure 3. Francesco Hayez, Meditation, oil on canvas, 1851, Verona, Galleria d'Arte Moderna Palazzo Forti 
book), to the ill-fated rebellion of 1848 (the dates on the cross), and to religion (the cross itself), and all of these juxtaposed elements converge on the image of the girl, who is also without a doubt very attractive and even highly erotic. This complex set of iconographic elements may be read as follows: Italy, after the defeat of the revolution, has no defences against the enemy, who will seek to threaten her liberty and her honour; the girl's gaze is sad, but also very resolute, as if she thinks that all is not yet lost, that honour can still be defended, if the patriots summon up their strength and hasten to protect and free her.

If this reading is correct, it also suggests that we have to do here with a thoroughly masculine way of looking at the nation. This should not be a cause for surprise, since nineteenth-century national discourse was spoken almost exclusively by male voices, and from a perspective not wholly lacking in misogynistic emphases (and in this regard, the propensity of the female body to become material and symbolic booty for enemy aggression conjures up a deeply disturbing vision of the relation between the sexes).

On the other hand, narratives of this kind - which are anyway far more widespread than is generally supposed - are particularly stirring and convincing, and therefore meaningful, because they harp on male honour, which was a fundamental value in nineteenth-century society, transposing it from a strictly private domain involving the protection of the women in one's own family, to a domain involving the protection of the nation's women, or the protection of the nation in the guise of a woman, in a sort of 'nationalisation' of the private and the familial. If this value is put in the context of a patriotic religion of sacrifice and sufferance - like in the two pictures by Hayez -, this further ennobles the ethic content of the message.

In conclusion, all the themes evocated by the deep images touch on delicate matters relating to the structure of individual personalities; and this essentially because the deep images are connected to the past, kinship, death, the sacred, as well as the erotic and sexual imaginary realm. As such, these intricate, but crucial, aspects of the language of nationality evidently dig deep into collective consciousness and touch highly sensitive chords. It is exactly this way of working, which characterises the national discourse, that stirs emotional responses and an emotional consideration of the political issues connected with the nation, with its rights and its aspirations. And I am convinced that a close attention to these specific dimensions of national discourse could enable a better understanding of that discourse's great performative force - a force that was capable of powerfully reconfiguring identities in nineteenth-century Europe. 


\section{NOTES}

1 George L. Mosse, The Nationalization of the Masses: Political Symbolism and Mass Movements in Germany from the Napoleonic Wars through the Third Reich, New York: H. Fertig, 1975; Idem, Nationalism and Sexuality: Respectability and Abnormal Sexuality in Modern Europe, New York: H. Fertig, 1985; Idem, Fallen Soldiers: Reshaping the Memory of the World Wars, New York: Oxford UP, 1990.

2 The analytical materials and the first conceptual elaborations related to the "deep images" have been presented in Alberto M. Banti, L'onore della nazione. Identità sessuali e violenza nel nazionalismo europeo dal XVIII secolo alla Grande Guerra, Turin: Einaudi, 2005; Idem, La nazione del Risorgimento. Parentela, santità e onore alle origini dell'Italia unita, Turin, Einaudi, 2006; Idem, "Conclusions: Performative Effects and 'Deep Images' in National Discourse", in Laurence Cole (ed.), Different Paths to the Nation. Regional and National Identities in Central Europe and Italy, 1830-70, Basingstoke: Palgrave Macmillan, 2007; and Alberto M. Banti and Paul Ginsborg, "Per una nuova storia del Risorgimento", in Alberto M. Banti and Paul Ginsborg (eds), Il Risorgimento (= Storia d'Italia. Annali 22), Turin: Einaudi, 2007.

3 My use of the term "biopolitics" derives from Michel Foucault, Society must be Defended: Lectures at the Collège de France, 1975-1976, ed. by M. Bertani and A. Fontana, transl. by D. Macey, London: Penguin, 2003, pp. 243-45, and Michel Foucault, Sécurité, territoire, population: cours au Collège de France, 1977-1978, ed. by Michel Senellart, under the supervision of F. Ewald and A. Fontana, Paris: Seuil 2004, pp. 23-25.

4 Giovanni Berchet, Opere, I, Poesie, ed. by Egidio Bellorini, Bari: Laterza, 1911.

5 Among the nationalist texts that contain stories of rape we find: Friedrich Schiller, Wilhelm Tell, 1804; Theodor Körner, Leyer und Schwerdt, 1814; Giacomo Leopardi, All'Italia, 1818; Walter Scott, Ivanhoe, 1819; Francesco Hayez, I Vespri siciliani, 1822, 1835, 1844-46; Etienne de Jouy; Hippolyte Bis; Gioacchino Rossini, Guillaume Tell, 1829, Italian. transl. C. Bassi, music by G. Rossini; Massimo d'Azeglio, Ettore Fieramosca, ossia la disfida di Barletta, 1833; Idem, Niccolò de' Lapi ovvero i Palleschie i Piagnoni, 1841; Francesco Domenico Guerrazzi, L'assedio di Firenze, 1836; Eugène Sue, Les Mystères du peuple, ou Histoire d'une famille de prolétaires à travers les âges, 1849-1857; Eugène Delacroix, L'enlèvement de Rebecca, 1846 and 1858; James Grant, First Love and Last Love: A Tale of Indian Mutiny, 1868; Giuseppe Garibaldi, Clelia ovvero Il governo dei preti, 1870; Idem, Cantoni il Volontario, 1870; Idem, I Mille, 1874; G. A. Henty, Rujub, the Juggler, 1893. For an analysis of these kind of narratives, see Banti, L'onore della nazione; Sandra Gunning, Race, Rape, and Lynching. The Red Record of American Literature, 1890-1912, Oxford: Oxford UP, 1996; Nancy L. Paxton, Writing under the Raj. Gender, Race, and Rape in the British Colonial Imagination, 1830-1947, New Brunswick, NJ: Rutgers UP, 1999; and Sabine Sielke, Reading Rape. The Rhetoric of Sexual Violence in American Literature and Culture, 1790-1990, Princeton: Princeton UP, 2002.

6 Clifford Geertz, "Religion as a Cultural System”, in idem, The Interpretation of Cultures, London: Fontana, 1993, p. 104.

7 Fernando Mazzocca, Francesco Hayez. Catalogo ragionato, Milan: Motta, 1994, p. 151.

8 See Fernando Mazzocca (ed.), Romantici e macchiaioli. Giuseppe Mazzini e la grande pittura europea, Milan: Skira, 2005. The catalogue of the exhibition, which was held in Genoa from October 2005 to February 2006, also contains the catalogue entries for the Meditazione of 1851 (which is reproduced here) and for an earlier version, from 1850. Both pictures were shown in that same exhibition (ibid., pp. 256-7). 